\title{
Thermodynamic study of POSS-based ionic liquids with various numbers of ion pairs
}

\author{
Kazuo Tanaka, Fumiyasu Ishiguro and Yoshiki Chujo
}

We have previously reported a polyhedral oligomeric silsesquioxane (POSS)-based room temperature ionic liquid (IL) that shows a melting temperature below $25^{\circ} \mathrm{C}$. The connection of ion pairs to POSS can significantly improve the thermal stability and decrease the melting temperatures of the ion pairs. To understand the mechanism of these changes induced by POSS, we studied the thermal properties of POSS derivatives with variable numbers of imidazolium-carboxylate ion pairs. Initially, it was found that a modified POSS with a larger number of ion pairs could be a thermally stable, room temperature IL. From the series of thermodynamic and conformational analyses, we concluded that the star-shaped distribution of ion pairs originating from the cubic framework are necessary to express the characteristic changes in the thermal properties of ion pairs connected to POSS. Polymer Journal (2011) 43, 708-713; doi:10.1038/pj.2011.54; published online 15 June 2011

Keywords: imidazolium salt; ionic liquid; POSS

\section{INTRODUCTION}

Nanostructured polymeric materials have attracted much attention as platforms for developing new series of ionic liquids (ILs), because there is much potential to demonstrate advanced functions originating not only from the component molecules but also from their structural and morphological characteristics. ${ }^{1-15}$ The increase in molecular weight and the presence of charges often cause an increase in the melting temperature. We have recently reported a polyhedral oligomeric silsesquioxane (POSS)-based room temperature IL that displays a melting temperature below $25^{\circ} \mathrm{C} .{ }^{16}$ The bonding of ion pairs to POSS significantly improved the thermal stability and decreased the melting temperatures, even with the significant increase in molecular weight. However, the mechanism of these changes caused by bonding to POSS remains unclear. In particular, which characteristics of POSS, such as the cubic structure or the rigidity of the silica cage, predominantly affect the thermal properties of ion pairs needs to be investigated. An understanding of the contribution of POSS to the thermodynamics of ILs can provide guidelines for future molecular designs for polymer- and macromolecule-based ILs.

The typical POSS molecule possesses a cubic structure represented by the formula $\mathrm{R}_{8} \mathrm{Si}_{8} \mathrm{O}_{12}$, in which the central hydrophobic core $\left(\mathrm{Si}_{8} \mathrm{O}_{12}\right)$ is functionalized with organic moieties $(\mathrm{R})$ at the eight vertices. ${ }^{17-24}$ In polar solvents, POSS can form a globular conformation and create a distinct hydrophobic space around the POSS core..$^{25-28}$ Such structural features can contribute to reduce the packing density and isolating the distal ion pairs. Moreover, the molecular motion of substituents of the POSS core can be efficiently restricted because of the rigidity of the silica framework. ${ }^{29}$ Indeed, POSS has been used as a filler for improving the thermal and mechanical properties of conventional plastics by suppressing the molecular rotation of polymer chains. ${ }^{30}$

Herein, we prepared a series of modified POSS with variable numbers of imidazolium-carboxylate pairs $(n=2,4,6$ and 8) and investigated the relationships between structures and thermal properties (Figure 1). We hypothesized that the larger number of ion pairs connected to POSS induced the star-shaped structure ${ }^{31}$ because of electron repulsion. Therefore, the modified POSS molecules should show low packing density. In contrast, the modified POSS molecules were able to aggregate and condense into smaller numbers of ion pairs because of the strong hydrophobicity of POSS. On the basis of these ideas about the conformation, we considered the thermodynamic behaviors of POSS-tethered ion pairs in this article.

\section{EXPERIMENTAL PROCEDURE}

General

${ }^{1} \mathrm{H}$ nucleic magnetic resonance (NMR) and ${ }^{13} \mathrm{C}$ NMR spectra were measured with a JEOL EX-400 $\left(400 \mathrm{MHz}\right.$ for ${ }^{1} \mathrm{H}$ and $100 \mathrm{MHz}$ for $\left.{ }^{13} \mathrm{C}\right)$ spectrometer (JEOL Ltd., Tokyo, Japan). ${ }^{29} \mathrm{Si}$ NMR spectra were measured with a JEOL JNMA400 $(80 \mathrm{MHz})$ spectrometer. The coupling constants ( $J$ value) are reported in Hertz. The chemical shifts are expressed in p.p.m. downfield from tetramethylsilane, using residual chloroform ( $\delta=7.24$ in ${ }^{1} \mathrm{H}$ NMR, $\delta=77.0$ in ${ }^{13} \mathrm{C}$ NMR) as an internal standard. The mass spectra were obtained on a JEOL JMS-SX102A. Water abundances were evaluated with a Karl-Fischer Moisture Titrator MKC501, Kyoto Electronics Manufacturing (Kyoto, Japan).

Bromide salt of imidazolium cation 1, [Bmim] Br

Freshly distilled 1-bromobutane $(42.82 \mathrm{ml}, 0.400 \mathrm{~mol})$ was added to distilled 1-methylimidazole $(16.42 \mathrm{~g}, 0.200 \mathrm{~mol})$ with vigorous stirring under nitrogen at $0{ }^{\circ} \mathrm{C}$. The mixture was stirred under nitrogen for 1 week at ambient 


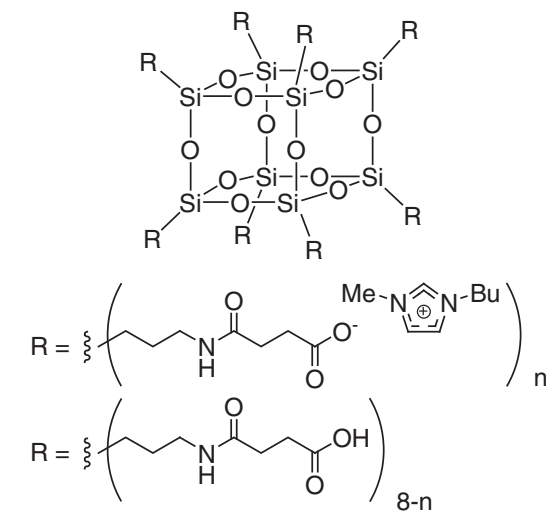

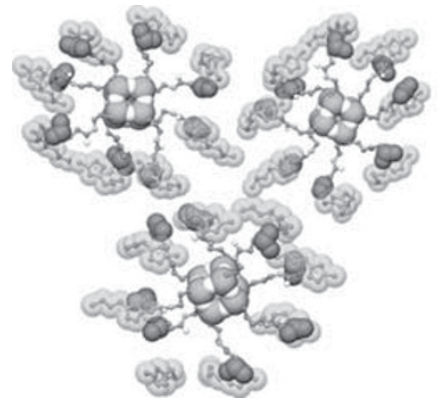

$\mathrm{n}=8$

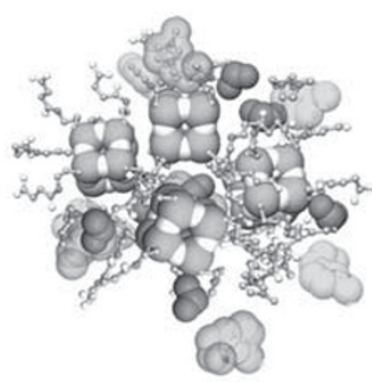

$\mathrm{n}=2$
Figure 1 Chemical structures and proposed conformations of the polyhedral oligomeric silsesquioxane-based ionic compounds. A full color version of this figure is available at Polymer Journal online.

temperature. After the reaction was completed, the excessive phase-separated 1-bromobutane was decanted. Then, the molten salt was washed with ethyl acetate and dried in vacuo at $50^{\circ} \mathrm{C}$ for $24 \mathrm{~h}$ to obtain compound $\mathbf{1}$ as a white solid $(42.8 \mathrm{~g}, 0.196 \mathrm{mmol}, 98 \%)$. The characterization was executed according to Huddleston et al. ${ }^{32}$

\section{Octaammonium POSS 3}

(3-Aminopropyl)triethoxysilane $(100 \mathrm{ml}, 0.427 \mathrm{~mol})^{25,33-35}$ and concentrated hydrochloric acid $(35-37 \%, 135 \mathrm{ml})$ in methanol $(800 \mathrm{ml})$ produced compound 5 as a white precipitate after 5 days at room temperature. The product was obtained after filtration, washing with cold methanol and drying. Compound 3 was spectroscopically pure at a $30 \%$ yield $(18.8 \mathrm{~g}) .{ }^{1} \mathrm{H}$ NMR (dimethyl sulfoxide (DMSO)- $\left.d_{6}\right) \delta 8.23(\mathrm{~s}, 24 \mathrm{H}), 2.76(\mathrm{t}, 16 \mathrm{H}), 1.71(\mathrm{~m}, 16 \mathrm{H}), 0.72$ $(\mathrm{t}, 16 \mathrm{H}) .{ }^{13} \mathrm{C}$ NMR (DMSO- $\left.d_{6}\right) \delta 40.53,20.13$ and $7.96 .{ }^{29} \mathrm{SiNMR}$ (DMSO- $d_{6}$ ) $\delta-66.4$ (s).

\section{Compound 4, POSS- $(\mathrm{COOH})_{8}$}

To a solution of compound $3(20.0 \mathrm{~g}, 17.0 \mathrm{mmol})$ and triethylamine $(20 \mathrm{ml}$, $14.4 \mathrm{mmol})$ in methanol $(1 \mathrm{l})$, succinic anhydride $(80 \mathrm{~g}, 0.80 \mathrm{~mol})$ was added, and the reaction mixture was stirred at room temperature for $2 \mathrm{~h}$ and then condensed by evaporation. ${ }^{25}$ Chloroform was poured into the reaction solution, and the white precipitation was collected via filtration and washed with chloroform and tetrahydrofuran. Subsequently, the product was resolved in $60 \mathrm{ml}$ of formic acid and reprecipitated by the addition of 11 of water. The white precipitation was filtered and washed with water until the filtrate indicated $\mathrm{pH}$ 7. The desired product 4 was obtained as a white solid after being dried in vacuo (19.2 g, $11.4 \mathrm{mmol}, 67 \%)$. ${ }^{1} \mathrm{H}$ NMR (DMSO- $\left.d_{6}\right) \quad \delta 0.59$ (br, 2H), 1.44 (br, 2H), 2.30 (br, 2H), 2.41 (br, 2H), 3.02 (br, $2 \mathrm{H}) .{ }^{13} \mathrm{C}$ NMR $\left(\right.$ DMSO-d $\left._{6}\right) \delta 8.74,22.48,29.15,29.98,41.00,170.92$ and $173.89 .{ }^{29} \mathrm{Si} \mathrm{NMR}$ (DMSO- $d_{6}$ ) $\delta-65.3$. Low-resolution mass spectrometry (LRMS; 3-nitrobenzyl alcohol $(\mathrm{NBA}))\left[(\mathrm{M}+\mathrm{H})^{+}\right]$calcd. 1680, found 1680. HRMS (NBA) $\left[\mathrm{M}+\mathrm{H}^{+}\right]$ calcd. 1680.4081, found 1680.4041 .

\section{Compound 6, Arm- $\mathrm{COOH}$}

Succinic anhydride $(60.0 \mathrm{~g}, 0.6 \mathrm{~mol})$ was dissolved into $200 \mathrm{ml}$ of dioxane, and propylamine $(35.4 \mathrm{~g}, 0.6 \mathrm{~mol})$ in $200 \mathrm{ml}$ of dioxane was slowly added. ${ }^{16}$ The solution was warmed to $80^{\circ} \mathrm{C}$ and stirred for $40 \mathrm{~min}$. The succinamic acid was crystallized by cooling after the reaction. The white crystal $\mathbf{6}$ was filtered, dried and recrystallized from dioxane $(76.2 \mathrm{~g}, 0.48 \mathrm{~mol}, 80 \%) .{ }^{1} \mathrm{H}$ NMR (DMSO- $d_{6}$ ) $\delta 0.79(\mathrm{t}, 3 \mathrm{H}, J=7.43 \mathrm{~Hz}), 1.37(\mathrm{~m}, 2 \mathrm{H}), 2.28(\mathrm{t}, 2 \mathrm{H}, J=6.76 \mathrm{~Hz}), 2.40(\mathrm{t}, 2 \mathrm{H}$, $J=6.76 \mathrm{~Hz}), 2.97(\mathrm{~m}, 2 \mathrm{H}) .{ }^{13} \mathrm{C}$ NMR (DMSO- $\left.d_{6}\right) \delta 11.37,22.37,29.20,30.00$, 40.29, 170.74, 173.84: LRMS (NBA) $\left[(\mathrm{M}+\mathrm{H})^{+}\right]$calcd. 160, found 160. HRMS (NBA) $\left[\mathrm{M}+\mathrm{H}^{+}\right]$calcd. 160.0974 , found 160.0978. Anal. calcd. for $\mathrm{C}_{7} \mathrm{H}_{13} \mathrm{NO}_{3}$ : C, 52.82; H, 8.23; N, 8.80; O, 30.15. Found: C, 52.71; H, 8.08; N, 8.80; O, 29.99.

\section{General procedure for the preparation of the ILs (5a-d, 7)}

The desired equivalent mole of bromide anion $\mathbf{1}$ for the carboxyl groups was converted into compound 2 by anion exchange resin (Amberlite-IRA400) in water and neutralized with each carboxyl compound suspended in methanol (21). ${ }^{16}$ The aqueous solution was concentrated by a rotary evaporator, and the residual liquid was freeze dehydrated to give a white solid. The solid was dried in vacuo and stored in a glove box. Arm-Im, 7: ${ }^{1} \mathrm{H}$ NMR (DMSO- $\left.d_{6}\right) \delta 0.82$ $(\mathrm{t}, 3 \mathrm{H}, J=7.43 \mathrm{~Hz}), 0.90(\mathrm{t}, 3 \mathrm{H}, J=7.31 \mathrm{~Hz}) 1.25(\mathrm{~m}, 2 \mathrm{H}) 1.35(\mathrm{~m}, 2 \mathrm{H})$ $1.74(\mathrm{~m}, 2 \mathrm{H}) 2.01(\mathrm{t}, 2 \mathrm{H}, J=6.76 \mathrm{~Hz}), 2.13(\mathrm{t}, 2 \mathrm{H}, J=6.76 \mathrm{~Hz}), 2.94$ $(\mathrm{m}, 2 \mathrm{H}) 3.85(\mathrm{~s}, 3 \mathrm{H}) 4.16(\mathrm{t}, 2 \mathrm{H}, J=7.19 \mathrm{~Hz}) 7.71(\mathrm{~m}, 1 \mathrm{H}) 7.78(\mathrm{~m}, 1 \mathrm{H})$ $9.04(\mathrm{~s}, 1 \mathrm{H}) 9.31(\mathrm{~s}, 1 \mathrm{H}) .{ }^{13} \mathrm{C}$ NMR (DMSO- $\left.d_{6}\right): \delta 11.41,13.25,18.76,22.47$, $31.38,33.80,34.90,35.59,40.12,48.36,122.21,123.55,137.24,173.38,174.70$. LRMS (NBA) $\left[\left(\mathrm{M}+\left[\mathrm{Bmim}^{+}\right]\right)^{+}\right]$calcd. 436, found 436. HRMS (NBA) $\left[\left(\mathrm{M}+\left[\mathrm{Bmim}^{+}\right]\right)^{+}\right]$calcd. 436.3282, found 436.3297. Anal. calcd. for $\mathrm{C}_{15} \mathrm{H}_{27} \mathrm{~N}_{3} \mathrm{O}_{3}$ : C, 60.58; H, 9.15; N, 14.13; Br, 0. Found: C, 57.26; H, 9.40; N, 13.43; Br, 0. POSS-Im2, 5a: ${ }^{1} \mathrm{H}$ NMR (DMSO- $\left.d_{6}\right) \delta 0.59(\mathrm{t}, 16 \mathrm{H}, J=7.92 \mathrm{~Hz})$ $0.90(\mathrm{t}, 6 \mathrm{H}, J=7.31 \mathrm{~Hz}) 1.26(\mathrm{~m}, 4 \mathrm{H}) 1.44(\mathrm{br}, 16 \mathrm{H}) 1.76(\mathrm{~m}, 4 \mathrm{H}) 2.27(\mathrm{br}$, $16 \mathrm{H}), 2.35$ (br, $16 \mathrm{H}), 3.00(\mathrm{~m}, 16 \mathrm{H}) 3.85(\mathrm{~s}, 6 \mathrm{H}) 4.16(\mathrm{t}, 4 \mathrm{H}, J=7.07 \mathrm{~Hz}) 7.74$ $(\mathrm{s}, 8 \mathrm{H}) 7.81(\mathrm{~s}, 8 \mathrm{H}) 8.98(\mathrm{~s}, 8 \mathrm{H}) 9.59(\mathrm{~s}, 8 \mathrm{H}) .{ }^{13} \mathrm{C}$ NMR (DMSO-d 6 ) $\delta 8.75$, 13.27, 18.77, 22.51, 30.61, 30.97, 31.34, 35.70, 40.93, 48.45, 122.13, 123.48, $136.42,171.28,174.28 .{ }^{29} \mathrm{Si}$ NMR (DMSO- $\left.d_{6}\right) \delta-66.1$. LRMS (NBA) $\left[(\mathrm{M}+\mathrm{H})^{+}\right]$calcd. 1959, found 1959. Anal. calcd. for $\mathrm{C}_{72} \mathrm{H}_{124} \mathrm{~N}_{12} \mathrm{O}_{36} \mathrm{Si}_{8}$ : C, 44.15 ; H, 6.38; N, 8.58; Br, 0. Found: C, 40.11; H, 6.17; N, 8.41; Br, 0. POSSIm4, 5b: ${ }^{1} \mathrm{H}$ NMR (DMSO- $\left.d_{6}\right) \delta 0.57(\mathrm{t}, 16 \mathrm{H}, J=7.92 \mathrm{~Hz}) 0.90(\mathrm{t}, 12 \mathrm{H}$, $J=7.31 \mathrm{~Hz}) 1.25(\mathrm{~m}, 8 \mathrm{H}) 1.42(\mathrm{br}, 16 \mathrm{H}) 1.76(\mathrm{~m}, 8 \mathrm{H}) 2.25(\mathrm{br}, 32 \mathrm{H}), 2.94(\mathrm{~m}$, $16 \mathrm{H}) 3.87(\mathrm{~s}, 24 \mathrm{H}) 4.16(\mathrm{t}, 8 \mathrm{H}, J=7.19 \mathrm{~Hz}) 7.74(\mathrm{~s}, 8 \mathrm{H}) 7.81(\mathrm{~s}, 8 \mathrm{H}) 8.98(\mathrm{~s}$, $8 \mathrm{H}) 9.59(\mathrm{~s}, 8 \mathrm{H}) .{ }^{13} \mathrm{C}$ NMR (DMSO- $\left.d_{6}\right) \delta 8.77,13.27,18.77,22.58,31.35$, $31.93,32.07,35.67,40.83,48.43,122.11,123.46,136.57,171.87,174.78 .{ }^{29} \mathrm{Si}$ NMR (DMSO- $\left.d_{6}\right) \delta-66.1$. LRMS (NBA) $\left[(\mathrm{M}+\mathrm{H})^{+}\right]$calcd. 2236, found 2236. Anal. calcd. for $\mathrm{C}_{88} \mathrm{H}_{152} \mathrm{~N}_{16} \mathrm{O}_{36} \mathrm{Si}_{8}$ : C, 47.29; H, 6.86; N, 10.03; Br, 0. Found: C, 42.54; H, 6.92; N, 9.70; Br, 0. POSS-Im6, 5c: ${ }^{1} \mathrm{H}$ NMR (DMSO- $\left.d_{6}\right) \delta 0.53$ $(\mathrm{t}, 16 \mathrm{H}, J=8.16 \mathrm{~Hz}) 0.89(\mathrm{t}, 18 \mathrm{H}, J=7.31 \mathrm{~Hz}) 1.25(\mathrm{~m}, 12 \mathrm{H}) 1.41(\mathrm{br}, 16 \mathrm{H}) 1.76$ (m, 12H) 2.15 (br, 16H), 2.19 (br, 16H), $2.95(\mathrm{~m}, 16 \mathrm{H}) 3.87(\mathrm{~s}, 18 \mathrm{H}) 4.17$ $(\mathrm{t}, 12 \mathrm{H}, J=7.19 \mathrm{~Hz}) 7.72(\mathrm{~s}, 8 \mathrm{H}) 7.79(\mathrm{~s}, 8 \mathrm{H}) 8.71(\mathrm{~s}, 8 \mathrm{H}) 9.38(\mathrm{~s}, 8 \mathrm{H}) .{ }^{13} \mathrm{C}$ NMR (DMSO- $\left.d_{6}\right) \delta 8.82,13.26,18.77,22.65,31.37,32.74,33.44,35.59$, $40.84,48.36,122.09,123.43,136.95,172.51,174.86 .{ }^{29} \mathrm{Si}$ NMR (DMSO- $d_{6}$ ) $\delta$-66.2. LRMS (NBA) $\left[(\mathrm{M}+\mathrm{H})^{+}\right]$calcd.2511, found 2511. Anal. calcd. for $\mathrm{C}_{104} \mathrm{H}_{180} \mathrm{~N}_{20} \mathrm{O}_{36} \mathrm{Si}_{8}$ : C, 49.74; H, 7.22; N, 11.15; Br, 0. Found: C, 44.76; H, 7.68; $\mathrm{N}, 10.71 ; \mathrm{Br}, 0$. POSS-Im8, 5d: ${ }^{1} \mathrm{H}$ NMR (DMSO- $\left.d_{6}\right) \delta 0.53(\mathrm{t}, 16 \mathrm{H}, J=8.16 \mathrm{~Hz})$ $0.88(\mathrm{t}, 24 \mathrm{H}, J=7.31 \mathrm{~Hz}) 1.23(\mathrm{~m}, 16 \mathrm{H}) 1.38(\mathrm{br}, 16 \mathrm{H}) 1.75(\mathrm{~m}, 16 \mathrm{H}) 2.05$ $(\mathrm{t}, 16 \mathrm{H}, J=7.09 \mathrm{~Hz}), 2.18(\mathrm{t}, 16 \mathrm{H}, J=7.09 \mathrm{~Hz}), 2.94(\mathrm{~m}, 16 \mathrm{H}) 3.87(\mathrm{~s}, 24 \mathrm{H}) 4.17$ $(\mathrm{t}, 16 \mathrm{H}, J=7.19 \mathrm{~Hz}) 7.74(\mathrm{~s}, 8 \mathrm{H}) 7.81(\mathrm{~s}, 8 \mathrm{H}) 8.98(\mathrm{~s}, 8 \mathrm{H}) 9.59(\mathrm{~s}, 8 \mathrm{H}) .{ }^{13} \mathrm{C}$ NMR (DMSO- $\left.d_{6}\right) \delta 8.88,13.26,18.77,22.68,31.39,33.51,34.74,35.54,40.83$, $48.30,122.09,123.41,137.28,173.12,174.76 .{ }^{29} \mathrm{Si}$ NMR (DMSO- $\left.d_{6}\right) \delta-66.2$. LRMS (NBA) $\left[(\mathrm{M}+\mathrm{H})^{+}\right]$calcd. 2787, found 2787. Anal. calcd. for $\mathrm{C}_{120} \mathrm{H}_{208} \mathrm{~N}_{24} \mathrm{O}_{36} \mathrm{Si}_{8}$ : C, 51.70; H, 7.52; N, 12.06; Br, 0. Found: C, 45.21; H, 7.70; N, 11.30; Br, 0 .

\section{Differential scanning calorimetry (DSC)}

DSC thermograms were carried out on an SII DSC 6220 instrument using approximately $10 \mathrm{mg}$ of exactly weighed samples. The sample on the aluminum open pan was cooled to $-130{ }^{\circ} \mathrm{C}$ at a rate of $10{ }^{\circ} \mathrm{C} \mathrm{min}^{-1}$ under flowing nitrogen $\left(30 \mathrm{ml} \mathrm{min}^{-1}\right)$ and then heated from -130 to $80^{\circ} \mathrm{C}$ at the same rate. The glass transition $\left(T_{\mathrm{g}}\right)$ and melting temperatures $\left(T_{\mathrm{m}}\right)$ were determined as the onset of the second curves to eliminate heat history. The fusion enthalpy 
$\left(\Delta H_{\text {fus }}\right)$ was calculated from the areas of the endothermic peaks at the first cycle with the completely crystallized samples soaked in the liquid nitrogen before the measurements.

\section{Thermogravimetric analysis (TGA)}

TGA was performed on an EXSTAR TG/DTA6220, Seiko Instrument (Seiko Instruments Inc., Chiba, Japan), with a heating rate of $10^{\circ} \mathrm{Cmin}^{-1}$ up to $900^{\circ} \mathrm{C}$ under flowing nitrogen $\left(200 \mathrm{ml} \mathrm{min}^{-1}\right)$. Residual water was removed by keeping the sample on the platinum pan at $110^{\circ} \mathrm{C}$ for $1 \mathrm{~h}$ before the curve profiling. The decomposition temperatures $\left(T_{\mathrm{d}}\right)$ were determined from the onset of the weight loss.

\section{RESULTS AND DISCUSSION}

The series of POSS samples with variable numbers of ion pairs were prepared according to Scheme 1. ${ }^{16,25,32-35}$ The formation of the ion pairs, $\left[\mathrm{R}-\mathrm{COO}^{-}\right]\left[\mathrm{Bmim}^{+}\right]$, was performed via acid-base neutralization using POSS- $(\mathrm{COOH})_{8}$ and $[\mathrm{Bmim}] \mathrm{OH} .{ }^{16}$ The stoichiometry between POSS and ion pairs was adjusted by changing the feeding ratios. To avoid the degradation of the POSS cage in the presence of excess $[\mathrm{Bmim}] \mathrm{OH}$, the reaction was performed by titration of the diluted $[\mathrm{Bmim}] \mathrm{OH}$ with a suspension of POSS- $(\mathrm{COOH})_{8}$. After being dried in vacuo, each product was obtained as a colorless and transparent product.

All samples containing the POSS moiety produced single peaks at -66 p.p.m. in the ${ }^{29} \mathrm{Si}$ NMR spectra assigned to the $\mathrm{T}_{8}$ POSS structure.
Integration of the peaks in the ${ }^{1} \mathrm{H}$ NMR spectrum indicated the formation of ion pairs with desired ratios and an imidazolium cation. The samples were stored in a glove box under an argon atmosphere, and the water abundance was kept below $1.5 \mathrm{wt} \%$, as determined by the Karl Fischer method. The concentration of residual bromide ion was lower than the detectable level in the elemental analysis. Therefore, we concluded that all products were sufficiently pure for the following analyses. We prepared the ion pair, Arm-Im, for comparison purposes to evaluate the effects of the connection to POSS.

The thermal stability of the synthetic compounds against pyrolysis was investigated by TGA. Figure $2 \mathrm{a}$ shows the TGA profiles of the synthetic compounds, and Table 1 summarizes the $T_{\mathrm{d}}$ values evaluated from the onsets of the TGA profiles. We observed two significant weight losses in all samples. Because similar molecular weights were obtained after the first weight loss, this step can be assigned as the degradation of the carboxyl groups (Figure $2 \mathrm{~b}$ ). Therefore, the $T_{\mathrm{d}}$ value represents the influence on the thermal stability of the carboxyl groups by introducing $\left[\mathrm{Bmim}^{+}\right]$to POSS. The $T_{\mathrm{d}}$ values of POSS-Im6 and POSS-Im8 were higher than those of Arm-Im and POSS$(\mathrm{COOH})_{8}$. On the contrary, POSS-Im2 and POSS-Im4 showed lower $T_{\mathrm{d}}$ values than those of Arm-Im and POSS- $(\mathrm{COOH})_{8}$. These results indicate that the larger number of ion pairs accumulated on POSS may be necessary to express the characteristic changes of thermal stability observed from POSS-Im6 and POSS-Im8. This is likely because the probability of blocking by imidazolium should

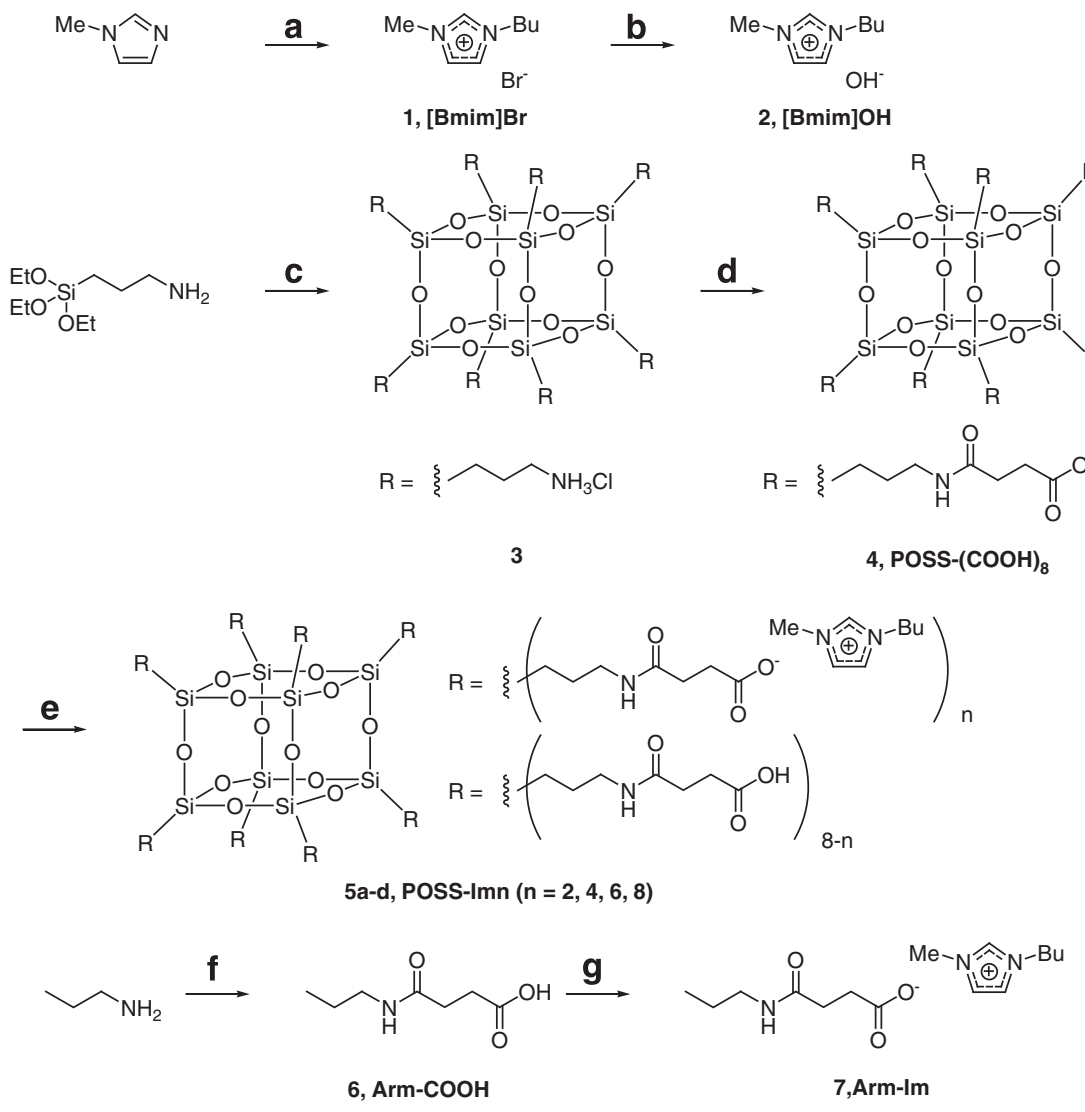

Scheme 1 Synthesis of the ionic compounds. Reagents and conditions: (a) butyl bromide, $0{ }^{\circ} \mathrm{C}$ to room temperature, 1 week, $98 \%$; (b) amberlite-IRA400, water, room temperature; (c) methanol, concentrated hydrochloric acid, room temperature, 5 days, 30\%; (d) succinic anhydride, triethylamine, methanol, room temperature, $2 \mathrm{~h}, 67 \%$; (e) compound 2, methanol, room temperature; (f) succinic anhydride, dioxane, $80{ }^{\circ} \mathrm{C}$, 40 min, $80 \%$; (g) compound 2 , methanol, room temperature. POSS, polyhedral oligomeric silsesquioxane. 
increase in these compounds from pyrolysis of free carboxyl groups. In addition, the existence of POSS can hardly contribute to improve thermal stability because less significant enhancements were observed
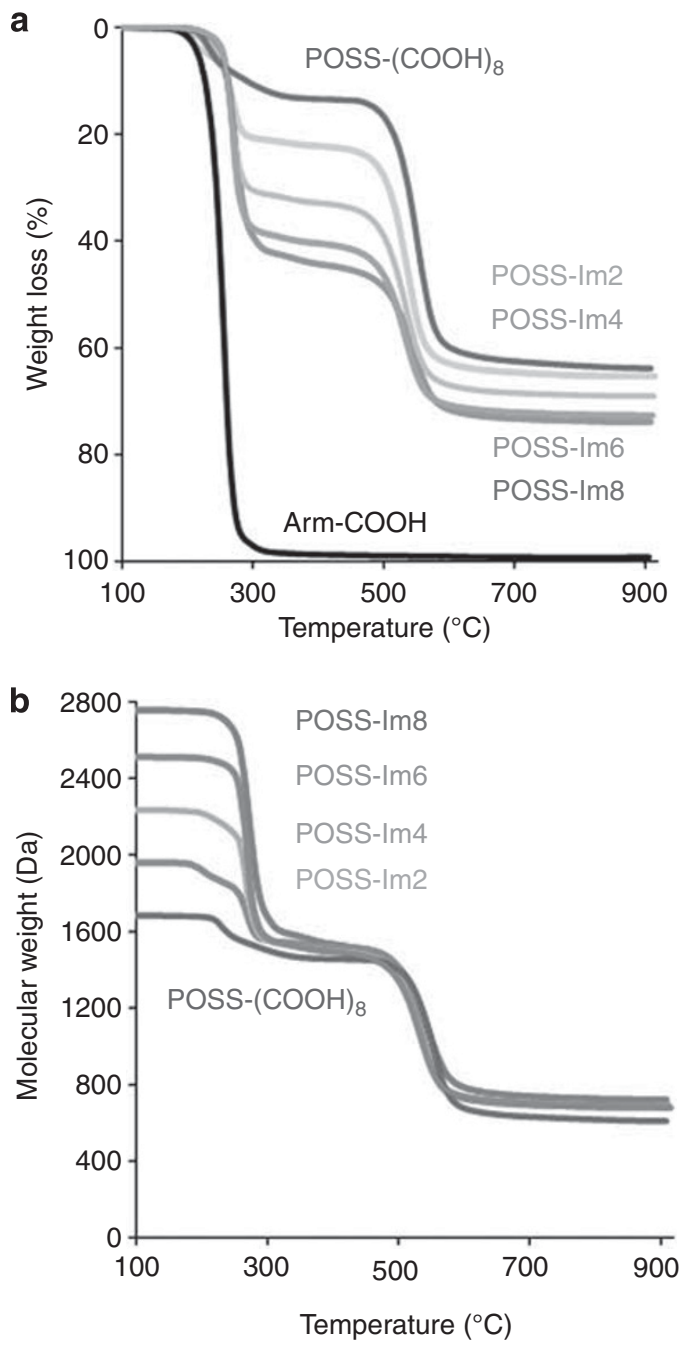

Figure 2 Thermogravimetric analysis thermograms of the ionic compounds under flowing nitrogen. POSS, polyhedral oligomeric silsesquioxane. A full color version of this figure is available at Polymer Journal online.

Table 1 Thermodynamic parameters of the ionic compounds determined from the DSC and TGA curves

\begin{tabular}{|c|c|c|c|c|c|c|}
\hline Salt & $\begin{array}{c}T_{d} \\
\left({ }^{\mathrm{a}}\right)^{\mathrm{a}}\end{array}$ & $\begin{array}{c}T_{m} \\
(C)^{\mathrm{b}}\end{array}$ & $\begin{array}{c}T_{m} \\
\left({ }^{\circ}\right)^{c}\end{array}$ & $\begin{array}{c}T_{g} \\
\left({ }^{c} \mathrm{c}\right.\end{array}$ & $\begin{array}{c}\Delta H_{\text {fus }} \\
\left(\mathrm{kJmol}^{-1}\right)^{\mathrm{b}}\end{array}$ & $\begin{array}{c}\Delta S_{f u s} \\
\left(\mathrm{Jmol}^{-1} \mathrm{~K}^{-1}\right)^{\mathrm{d}}\end{array}$ \\
\hline Arm-Ime & 202 & 49 & 48 & -40 & 15 & 47 \\
\hline POSS-Im8 & 234 & 45 & 23 & -52 & 6.8 & 21 \\
\hline POSS-Im6 & 233 & 44 & 19 & -55 & 11 & 35 \\
\hline POSS-Im4 & 188 & 59 & ND & ND & 39 & 120 \\
\hline POSS-Im2 & 165 & 142 & ND & ND & 41 & 99 \\
\hline
\end{tabular}

Abbreviations: DSC, differential scanning calorimetry; $H_{\text {fus }}$, fusion enthalpy; ND, not determined; POSS, polyhedral oligomeric silsesquioxane; $S_{\text {fus }}$, fusion entropy; $T_{\mathrm{d}}$, decomposition temperature; $T_{\mathrm{g}}$, glass transition; TGA, thermogravimetric analysis; $T_{\mathrm{m}}$, melting temperature. a Determined from the onsets in the TGA curves in Figure 2.

bobtained from the first heating curves in the DSC experiments.

cDetermined from the second heating curves.

${ }^{\mathrm{d}}$ Calculated from the following relation: $\Delta S_{\text {fus }}=\Delta H_{\text {fus }} / T_{\mathrm{m}}$.

eReference Fernicola et al. ${ }^{3}$ from POSS-Im2 and POSS-Im4. These results imply that the thermal properties of POSS-based ILs might be influenced not by the rigidity but by the structural feature of POSS. It should be mentioned that there should be distinct differences in properties between POSS-Im4 and POSS-Im6.

The DSC analysis was performed at a heating rate of $10^{\circ} \mathrm{C} \mathrm{min}-1$ (Figure 3). The $T_{\mathrm{m}}$ values of the obtained compounds are listed in Table 1. Endothermic peaks assigned to the melting process were observed below $100^{\circ} \mathrm{C}$ from each of the POSS-containing compounds except POSS-Im2. Therefore, POSS-Im4, POSS-Im6 and POSS-Im8 can be categorized as ILS. Remarkably, POSS-Im6 and POSS-Im8 showed melting below $25^{\circ} \mathrm{C}$ for the second cycle. Thus, they can be classified as a room temperature ILs. The $T_{\mathrm{m}}$ values of POSS-Im6 and POSS-Im8 were 19 and $23^{\circ} \mathrm{C}$ lower than that of Arm-Im. In contrast, POSS-Im 2 and POSS-Im 4 showed less significant $T_{\mathrm{m}}$ values below $100^{\circ} \mathrm{C}$. These data clearly indicate that a large number of ion pairs may be required for decreasing the $T_{\mathrm{m}} \mathrm{s}$ of POSS-tethered ion compounds. From these results involving the TGA data, it can be summarized that the accumulation of a larger number of ion pairs on POSS is essential to obtain the characteristic thermal property of POSS-based ILs. In addition, the rigidity of POSS seems to have less of an effect on the thermal properties. Corresponding to the results of TGA, there should be significant differences in the properties of POSS-Im4 and POSS-Im6.

To understand the thermodynamics of the melting process of ion pairs, the fusion enthalpies and entropies $\left(\Delta H_{\text {fus }}\right.$ and $\left.\Delta S_{\text {fus }}\right)$ per single imidazolium molecule were evaluated from the areas of the endothermic peaks observed in the DSC profiles (Table 1). Lower $\Delta H_{\text {fus }}$ values than that of Arm-Im, which is a characteristic of a POSS-based IL, were observed for POSS-Im6 and POSS-Im8. Conversely, POSS-Im2 and POSS-Im4 showed larger values of $\Delta H_{\text {fus }}$. These results can be explained by the structural features of POSS. The star-shaped structures of the modified POSS molecules could be induced by electrostatic repulsion, resulting in the isolation of the distal ion pairs and large exclusive volumes. ${ }^{31}$ These structures should disrupt the formation of the thermally stable conformation and reduce the

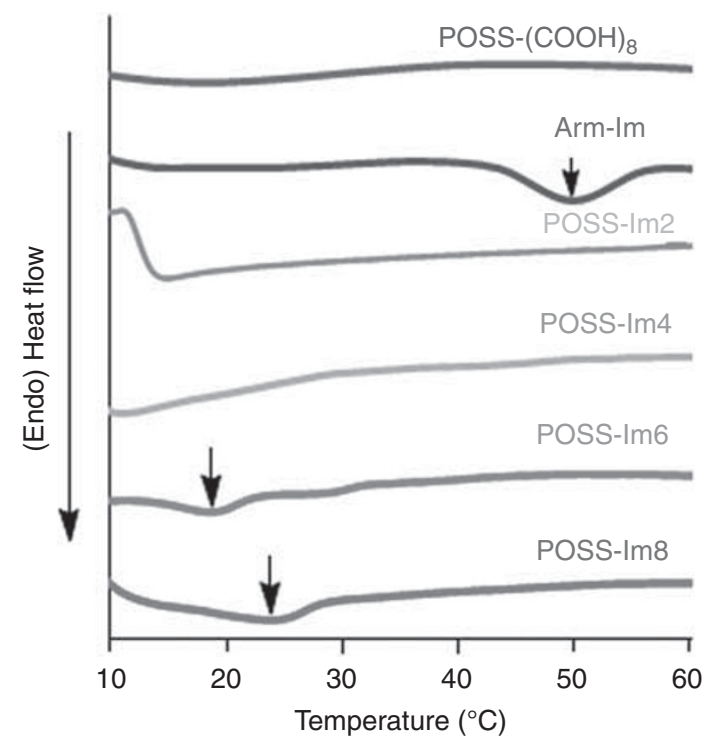

Figure 3 The differential scanning calorimetry curves of the ionic compounds for the second scan. POSS, polyhedral oligomeric silsesquioxane. A full color version of this figure is available at Polymer Journal online. 


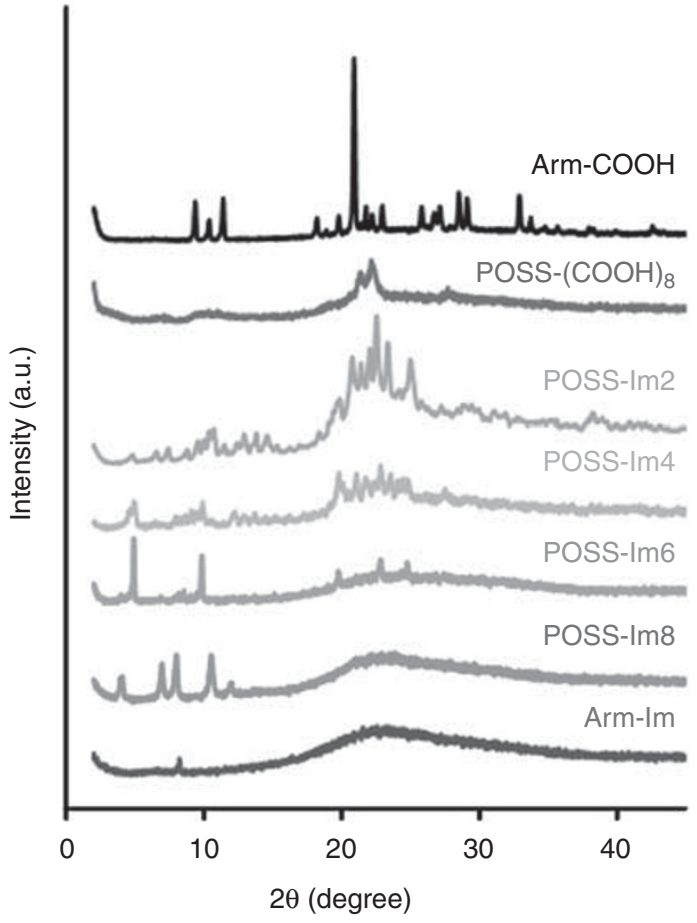

Figure $4 \mathrm{X}$-ray diffraction analysis patterns of the ionic compounds. POSS, polyhedral oligomeric silsesquioxane. A full color version of this figure is available at Polymer Journal online.

packing density. Thus, the interaction between the POSS molecules could be weakened in POSS-Im6 and POSS-Im8. Moreover, smaller values of $\Delta S_{\text {fus }}$ for POSS-Im6 and POSS-Im8 can also support the contribution of the structural features of POSS to the thermal properties. The star-shaped structure should reduce the conformational variety of the ion pairs because of the higher symmetry. ${ }^{36}$ In addition to the intrinsic symmetry of the cubic structure of POSS, POSS-Im6 and POSS-Im8 should show much smaller $\Delta S_{\text {fus }}$ values. These data can be summarized as follows. When a larger number of ion pairs are accumulated on POSS, the star-shaped structure should be induced. Larger exclusive volumes and higher symmetry of the POSS molecules could reduce the intermolecular interaction. Hence, the melting temperatures could decrease.

To support the conformational speculation, X-ray diffraction analysis analysis was performed (Figure 4). From the samples of POSS$\operatorname{Im} 6$ and POSS-Im8, several peaks in the region from $2 \theta=5^{\circ}(d=17 \AA)$ to $15^{\circ}(d=6 \AA)$ were observed. In contrast, dispersed patterns were obtained around $2 \theta=23^{\circ}(d=4 \AA)$ from POSS-Im2 and POSS-Im 4 . These results indicate that POSS-Im6 and POSS-Im8 can involve large regular structures. It is implied that star-shaped structures of POSSIm6 and POSS-Im8 could create the exclusive areas around the POSS core. In the case of POSS-Im2 and POSS-Im4, it was presumed that the aggregation at the POSS moiety because of the hydrophobic interaction and at the ionic groups because of the electrostatic interaction could induce the miscellaneous conformation. These assumptions can be supported by the conformation.

The chemical shifts of the peak assigned as the two-position of imidazolium were compared in the ${ }^{1} \mathrm{H}$ NMR spectra (Figure 5). It has been reported that the strength of the solubilizing ability of cellulose by imidazolium-based ILs can be evaluated from the width of the downfield shift of this peak. ${ }^{37}$ Correspondingly, by increasing the

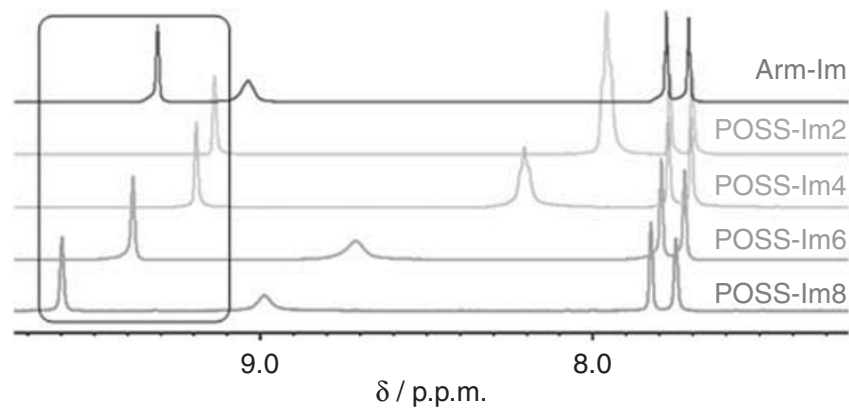

Figure $5{ }^{1} \mathrm{H}$ nucleic magnetic resonance spectra of the ionic compounds in dimethyl sulfoxide at $25^{\circ} \mathrm{C}$. POSS, polyhedral oligomeric silsesquioxane. A full color version of this figure is available at Polymer Journal online.

number of ion pairs, the peak position showed a larger downfield shift. These data suggest that the strength of hydrogen bonds was significantly enhanced in POSS-Im6 and POSS-Im8. Exclusion volumes originating from the star-shaped structure could generate hydrophobic spaces inside molecules. It was implied that the strength of the hydrogen bonding might be enhanced by locating it at relatively hydrophobic spaces.

\section{CONCLUSION}

In conclusion, we present findings indicating that POSS-tethered imidazolium salts can work as room temperature ILs, despite the inclusion of modified POSS, which has multiple ion pairs in a single molecule. We demonstrate the significance of the cubic structure of POSS to show the characteristic thermal properties in POSS-based molten salts. It was suggested that the increase of thermal stability and the decrease of melting temperatures of ion pairs tethered to POSS should originate from the star-shaped structure created by the cubic framework. These results imply that by replacing the carboxyl group with other thermally stable anions, POSS-based ILs could be improved. In addition, it was demonstrated that the strength of the hydrogen bonding of carboxyl groups can be significantly enhanced by connecting them to POSS. POSS might create distinct hydrophobic spaces. These results suggest that POSS-ILs might be applicable as a superior medium for solubilizing polysaccharides or other insoluble materials. Our findings described here are important not only for modulating the functions of ILs but also for designing new advanced ILs based on POSS.

\section{ACKNOWLEDGEMENTS}

This work is partly supported by the Iketani Science and Technology Foundation (for KT).

1 Ohno, H. Molten salt type polymer electrolytes. Electrochim. Acta 46, 1407-1411 (2001).

2 Fukushima, T. \& Aida, T. Ionic liquids for soft functional materials with carbon nanotubes. Chem. Eur. J. 13, 5048-5058 (2007).

3 Fernicola, A., Panero, S., Scrosati, B., Tamada, M. \& Ohno, H. New types of Brönsted acid-base ionic liquids-based membranes for applications in PEMFCs. ChemPhysChem 8, 1103-1107 (2007).

4 Mukai, K., Asaka, K., Sugino, T., Kiyohara, K., Takeuchi, I., Terasawa, N., Futaba, D. N., Hata, K., Fukushima, T. \& Aida, T. Highly conductive sheets from millimeter-long single-walled carbon nanotubes and ionic liquids: application to fast-moving, low-voltage electromechanical actuators operable in air. Adv. Mater. 21, 1582-1585 (2009).

5 Ueki, T. \& Watanabe, M. Macromolecules in ionic liquids: progress, challenges, and opportunities. Macromolecules 41, 3739-3749 (2008). 
6 Lu, J., Yan, F. \& Texter, J. Advanced applications of ionic liquids in polymer science. Prog. Polym. Sci. 34, 431-448 (2009).

7 Yoshio, M., Kagata, T., Hoshino, K., Mukai, T., Ohno, H. \& Kato, T. One-dimensional ion-conductive polymer films: alignment and fixation of ionic channels formed by self-organization of polymerizable columnar liquid crystals. J. Am. Chem. Soc. 128, 5570-5577 (2006).

8 Egashira, M., Todo, H., Yoshimoto, N. \& Morita, M. Lithium ion conduction in ionic liquid-based gel polymer electrolyte. J. Power Sources 178, 729-735 (2008).

9 Mori, H., Yahagi, M. \& Endo, T. RAFT polymerization of $N$-vinylimidazolium salts and synthesis of thermoresponsive ionic liquid block copolymers. Macromolecules 42 , 8082-8092 (2009).

10 Matsumi, N., Kagata, A. \& Aoi, K. Synthesis of supramolecular solid polymer electroIytes via self-assembly of diborylated ionic liquid. J. Power Sources 195, 6182-6186 (2010).

11 Ujiie, S. \& limura, K. Thermal properties and orientational behavior of a liquidcrystalline ion complex polymer. Macromolecules 25, 3174-3178 (1992)

12 Jovanovski, V., Orel, B., Ješe, R., Vuk, A.S., Mali, G., Hoèevar, S. B., Grdadolnik, J., Stathatos, E. \& Lianos, P. Novel polysilsesquioxane- $-I^{-} / I_{3}^{-}$ionic electrolyte for dye-sensitized photoelectrochemical cells. J. Phys. Chem. B 109, 14387-14395 (2005).

13 Jovanovski, V., Orel, B., Ješe, R., Mali, G., Stathatos, E. \& Lianos, P. Positively charged polysilsesquioxane/iodide Ionic liquid as a quasi solid-state redox electrolyte for dye-sensitized photo electrochemical cells: Infrared, ${ }^{29} \mathrm{Si} \mathrm{NMR}$, and electrical studies. Int. J. Photoenergy 8, 1-8 (2006).

14 Vuk, A.Š., Jovanovski, V., Pollet-Villard, A., Jerman, I. \& Orel, B. Imidazolium-based ionic liquid derivatives for application in electrochromic devices. Sol. Energy Mater. Sol. Cells 92, 126-135 (2008).

15 Subianto, S., Mistry, M. K., Choudhury, N. R., Dutta, N. K. \& Knott, R. Composite polymer electrolyte containing ionic liquid and functionalized polyhedral oligomeric silsesquioxanes for anhydrous PEM applications. ACS Appl. Mater. Interfaces 6, 1173-1182 (2009).

16 Tanaka, K., Ishiguro, F. \& Chujo, Y. POSS ionic liquid. J. Am. Chem. Soc. 132, 17649-17651 (2010)

17 Laine, R. M. Nanobuilding blocks based on the [OSiO1.5]x ( $x=6,8,10)$ octasilsesquioxanes. J. Mater. Chem. 15, 3725-3744 (2005).

18 Cordes, D. B., Lickiss, P. D. \& Rataboul, F. Recent developments in the chemistry of cubic polyhedral oligosilsesquioxanes. Chem. Rev. 110, 2081-2173 (2010).

19 Liu, H., Kondo, S., Takeda, N. \& Unno, M. Synthesis of octacarboxy spherosilicate. J. Am. Chem. Soc. 130, 10074-10075 (2008).

20 Mitsuishi, M., Zhao, F., Kim, Y., Watanabe, A. \& Miyashita, T. Preparation of ultrathin silsesquioxane nanofilms via polymer Langmuir-Blodgett films. Chem. Mater. 20, 4310-4316 (2008)

21 Wu, S., Hayakawa, T., Kikuchi, R., Grunzinger, S. J., Kakimoto, M. \& Oikawa, H. Synthesis and characterization of semiaromatic polyimides containing POSS in main chain derived from double-decker-shaped silsesquioxane. Macromolecules 40, 5698-5705 (2007).
22 Hosaka, N., Torikai, N., Otsuka, H. \& Takahara, A. Structure and dewetting behavior of polyhedral oligomeric silsesquioxane-filled polystyrene thin films. Langmuir 23, 902-907 (2007).

23 Tanaka, K., Kitamura, N., Naka, K. \& Chujo, Y. Multi-modal ${ }^{19} \mathrm{~F}$ NMR probe using perfluorinated cubic silsesquioxane-coated silica nanoparticles for monitoring enzymatic activity. Chem. Commun. 6176-6178 (2008).

24 Tanaka, K., Kitamura, N., Takahashi, Y. \& Chujo, Y. Reversible signal regulation system of ${ }^{19} \mathrm{~F}$ NMR by redox reactions using a metal complex as a switching module. Bioorg. Med. Chem. 17, 3818-3823 (2009).

25 Tanaka, K., Inafuku, K., Adachi, S. \& Chujo, Y. Tuning of properties of POSS-condensed water-soluble network polymers by modulating the cross-linking ratio between POSS. Macromolecules 42, 3489-3492 (2009).

26 Tanaka, K., Inafuku, K. \& Chujo, Y. Environment-responsive upconversion based on dendrimer-supported efficient triplet-triplet annihilation in aqueous media. Chem. Commun. 46, 4378-4380 (2010).

27 Tanaka, K., Inafuku, K., Naka, K. \& Chujo, Y. Enhancement of entrapping ability of dendrimers by a cubic silsesquioxane core. Org. Biomol. Chem. 6, 3899-3901 (2008).

28 Tanaka, K., Inafuku, K. \& Chujo, Y. Ratiometric multimodal chemosensors based on cubic silsesquioxanes for monitoring solvent polarity. Bioorg. Med. Chem. 16, 10029-10033 (2008)

29 Tanaka, K., Kitamura, N., Naka, K., Morita, M., Inubushi, T., Chujo, M., Nagao, M. \& Chujo, Y. Improving proton relaxivity of dendritic MRI contrast agents by rigid silsesquioxane core. Polym. J. 41, 287-292 (2009).

30 Tanaka, K., Adachi, S. \& Chujo, Y. Structure-property relationship of octa-substituted POSS in thermal and mechanical reinforcements of conventional polymers. J. Polym. Sci. Part A: Polym. Chem. 47, 5690-5697 (2009).

31 Tanaka, K., Adachi, S. \& Chujo, Y. Side-chain effect of octa-substituted POSS fillers on refraction in polymer composites. J. Polym. Sci. Part A: Polym. Chem. 48, 5712-5717 (2010).

32 Huddleston, J. G., Willauer, H. D., Swatloski, R. P., Visser, A. E. \& Rogers, R. D. Room temperature ionic liquids as novel media for 'clean' liquid-liquid extraction. Chem. Commun. 1765-1766 (1998).

33 Gravel, M.- C. \& Laine, R. M Synthesis and characterization of a new aminofunctionalized silsesquioxane. Polym. Prepr. (Am. Chem. Soc. Div. Polym. Chem.) 38, 155-156 (1997).

34 Feher, F. J. \& Wyndham, K. D. Amine and ester-substituted silsesquioxanes: synthesis, characterization and use as a core for starburst dendrimers. Chem. Commun. 323-324 (1998).

35 Gravel, M.- C., Zhang, C., Dinderman, M. \& Laine, R. M. Octa(3-chloroammoniumpropyl) octasilsesquioxane. Appl. Organometal. Chem. 13, 329-336 (1999).

36 Asuncion, M. Z., Ronchi, M., Abu-Seir, H. \& Laine, R. M. Synthesis, functionalization and properties of incompletely condensed 'half cube' silsesquioxanes as a potential route to nanoscale Janus particles. C. R. Chimie. 13, 270-281 (2010).

$37 \mathrm{Xu}$, A., Wang, J. \& Wang, H. Effects of anionic structure and lithium salts addition on the dissolution of cellulose in 1-butyl-3-methylimidazolium-based ionic liquid solvent systems. Green Chem. 12, 268-275 (2010). 